UDC 665.4/6 621.892.0099.6

\title{
LUBRICATING COMPOSITIONS FOR SUPERCHARGED AND UNSUPERCHARGED HIGH-PERFORMANCE DIESEL ENGINES
}

\author{
Y.B. Ramazanova \\ Acad. A.M.Guliyev Institute of Chemistry of Additives \\ National Academy of Sciences of Azerbaijan \\ Beyukshor Highway, quarter 2062, Baku, AZ 1029, Republic of Azerbaijan \\ Phone: +994503277550; e-mail: pishnamazzadeh@mail.ru
}

Received 05.04.2019

\begin{abstract}
Permanent improvement of metal structures of up-to-date diesel engines actualizes creation of new, higher quality analogues of motor oils. For some time past the goal-oriented studies into application of multifunctional alkylphenolate additives $A K I\left(C_{8}-C_{12}\right)$ series as calcium salts of formaldehyde condensation with various amines ended in the creation of new lubricants of $M-10 \Gamma_{2} k$ u M-14 $\Gamma_{2}$ (API CC, SAE 15W-30; API CC, SAE 15W--40) grades.

Experimental samples of lubricant compositions based on compound of basic oils $M-8$ and $M$ 12 obtained from Baku oils, alkylphenol additives synthesized at the Institute of Chemistry of Additives and viscous additives of Viscoplex $(V)$ series of «Evonik» firm have been appraised by the results of qualification tests on Д-240 engine.
\end{abstract}

Keywords: motor oil, additive, lubricating compositions, engine tests, corrosion, wear

DOI: 10.32737/2221-8688-2019-2-282-290

\section{Introduction}

Continuous improvement of metal constructions in modern diesel engines makes it necessary to prodice new, more qualitative analogues of motor oils used in these engines.

The solution of economic and ecological problems accounts for carrying out research work into substitution of some long-term used additives with new generation additives.

Depending on the type of technology, an import task is to select various motor oils. A number of new multifunctional alkylphenolate aditives - AKI-130; 150; 115B; 210; 219 were synthesized as a result of long-term studies carried out at the Institute of Chemistry of Additives. Accelerated, high-energy supercharged and unsupercharged API CC

motor oils were developed using these additives and additives of some foreign companies, specifically for automobiles, auto tractors, ships, industrial and stationary diesels: multifunctional AKI-115B (calcium salt of condensation product of alkylphenol with formaldehyde, monoethanolamine and boric acid), AKI-150 (carbonated calcium salt of condensation product of alkylphenol with formaldehyde and aminoacetic acid), viscosity additives Viscoplex-8-450; 4-550 (relevantly), as well as various additives, M-8 and M-12 compound from Baku oils as base oils were used to develop motor oils for SAE-30accelerated auto tractor diesels, SAE-40 diesel locomotive and industrial diesel engines [1-4].

\section{Experimental part}

Newly developed motor oils are prepared by means of mixing the components of motor oils. Viscoplex viscosity additives V8-450, V-4-550 (correspondingly) are added into previously heated $\left(70-80^{\circ}\right)$ base oils and mixed at this temperature, then the remaining additives are added in a calculated quantity and mixed again.

The content of prepared new lubricating compositions is as follows: 
$\mathrm{M}-10 \Gamma_{2 \underline{\mathrm{K}}}: \quad \mathrm{M}-8+0.5 \%$ Viscoplex-8-450 +5.0\% AKI $-115 \mathrm{~B}+0.8 \% \mathrm{DF}-11+$ $0,5 \%$ C-400+ 0,4\%Viscoplex-5-309+0,003\% PMS-200A

M-14 $\Gamma_{2}: \quad$ M-8+M-12(50:50) 2,4\% Viscoplex $-4-550+4,0 \%$ AKI-150+1,5\% C-150 + 0,8\% A-22+ 0,5\% Viscoplex-5-309 + 0,003\% PMS-200A Quality parameters of base oils are cited below:

Quality parameters

Kinematic viscosity, $\mathrm{mm}^{2} / \mathrm{s}$

$40{ }^{\circ} \mathrm{C}$

$100{ }^{0} \mathrm{C}$

Viscosity index

Combustion temperature, ${ }^{0} \mathrm{C}$

Density, $\mathrm{kg} / \mathrm{m}^{3}, 20{ }^{\circ} \mathrm{C}$

Freezing point, ${ }^{0} \mathrm{C}$

Coke, $\%$
M-8

70.22

7.76

72.0

210.0

895.0

6.0

0.12
M-12

147.98

12.46

75.0

230.0

900.0

15.0

0.26
Standard limit of viscosity index of modern oils produced by various technological schemes is provided through the use of polymethacrylate viscosity additives.

It should be noted that growing viscosity properties and viscosity index of additives are different.

Thus, the following is required to increase the kinematic viscosity of:

Viscoplex-3-950 > Viscoplex-1-810> PMA«D»> Viscoplex-8-450 > Viscoplex-4$550>$ Shellvis-50 >Eridan B- 1751.

To increase the viscosity index of:
Viscoplex-3-950 >Viscoplex-1-810> Viscoplex-8-450 > Eridan B-1751 > PMA «D» $>$ Viscoplex-4-550> Shellvis-50.

It should be noted that the use of Viscoplex-8-450; -4-550; 2-670; 1-810 and additives from these series in creation of new compositions is preferable $[5,6]$.

This advantage is also based on the test results of mechanical and thermal destruction of additives explored. The use of viscosity additives was accounted for by studying their mechanical and thermal destruction properties.

\section{Results and discussion}

Mechanical destruction of viscosity additives used in preparation of new compositions was determined at УЗДН-2Т ultrasonic dispersant $22 \mathrm{kHs}$ with vibration pressure for $60 \mathrm{~min}$. by ГОСТ 6794-75, paragraph 3.6 (Table 1).

Table 1. Test results of mechanical destruction of polymethacrylate viscosity additives in M-12 oil (sound time, $60 \mathrm{~min}$.)

\begin{tabular}{|c|c|c|c|c|c|c|c|c|}
\hline \multirow{5}{*}{ Parameters } & \multicolumn{8}{|c|}{ M-12 oil } \\
\hline & \multicolumn{5}{|c|}{ Viscoplex } & \multirow{2}{*}{$\begin{array}{l}\text { Eridan } \\
\text { B-1751 }\end{array}$} & \multirow{2}{*}{$\begin{array}{l}\text { Shelvis } \\
-50\end{array}$} & \multirow{2}{*}{$\begin{array}{l}\text { ПМА } \\
\text { «Д» }\end{array}$} \\
\hline & $2-670$ & $1-810$ & $8-450$ & $4-550$ & $3-950$ & & & \\
\hline & \multicolumn{8}{|c|}{ Concentration of viscosity additives in oil, $\%$} \\
\hline & 1.2 & 2.7 & 2.4 & 3.3 & 2.55 & 0.5 & 0.37 & 3.0 \\
\hline $\begin{array}{l}\text { Kinematic } \\
\text { viscosity, } \mathrm{mm}^{2} / \mathrm{s}, \\
100^{\circ} \mathrm{C}\end{array}$ & 1308 & 1304 & 1383 & 1363 & 1414 & 1365 & 1386 & 1302 \\
\hline Dervie esting & 10.0 & דלת 10 ד & 10.00 & 10.00 & 1ד.14 & 15.00 & 15.00 & 10.92 \\
\hline
\end{tabular}




\begin{tabular}{|l|c|c|c|c|c|c|c|c|}
\hline \hline After testing & 13.12 & 12.97 & 12.18 & 13,06 & 11.48 & 13.08 & 13.21 & 13.40 \\
Viscosity change, \% & 6.1 & 6.95 & 11.98 & 4.1 & 18.8 & 4.17 & 4.68 & 3.63 \\
\hline
\end{tabular}

According to Table above, the destruction degree of viscosity additives with various structures and compositions against mechanical impacts are different. Note that the destruction resistance of co-polymer and polymethacrylate additives of Eridan, Shell and the Russian Federation is weaker than Viscoplex additives of Evoniк.

Research into the thermal destruction and proper selection makes it possible to reduce the engine oil consumption used in all seasons.
It should be added that the destruction of polymer compounds at high temperatures used for the improvement of viscositytemperature properties of oils reduces viscosity, viscosity index, combustion temperature.

To study the thermal destruction of the additives, their samples of optimal thickness were examined by well-known methods [7]. The viscosity and viscosity changes were determined through heating for 1 to 12 hours at $200^{\circ} \mathrm{C}$ (table 2 ).

Table 2. Determination of viscosity changes of additives at optimum concentrations

\begin{tabular}{|c|c|c|c|c|c|c|c|c|}
\hline \multirow{2}{*}{$\begin{array}{c}\text { Viscoplex } \\
\text { additive } \\
\text { samples in } \\
\text { M-12 oil }\end{array}$} & \multicolumn{7}{|c|}{ Stability index of viscosity, } & \multicolumn{7}{c|}{ Viscosity change, \% } \\
\cline { 2 - 10 } & 1 & 4 & 8 & 12 & 1 & 4 & 8 & 12 \\
\cline { 2 - 10 } & & & & & & & & \\
\hline $1,2 \%$ V-2-670 & 96.49 & 93.77 & 93.56 & 93.70 & 3.57 & 6.22 & 6.43 & 6.29 \\
\hline $2,7 \%$ V- 1-810 & 99.21 & 97.63 & 96.98 & 96.12 & 0.78 & 2.36 & 3.01 & 3.87 \\
\hline $2,4 \%$ V-8-450 & 99.34 & 99.71 & 97.54 & 96.96 & 0.28 & 0.65 & 2.45 & 3.08 \\
\hline $3,3 \%$ V-4-550 & 97.50 & 97.65 & 97.35 & 96.11 & 2.56 & 2.34 & 2.71 & 3.88 \\
\hline $2,5 \%$ V-3-950 & 97.17 & 92.50 & 91.44 & 89.53 & 2.82 & 7.49 & 8.55 & 10.46 \\
\hline
\end{tabular}

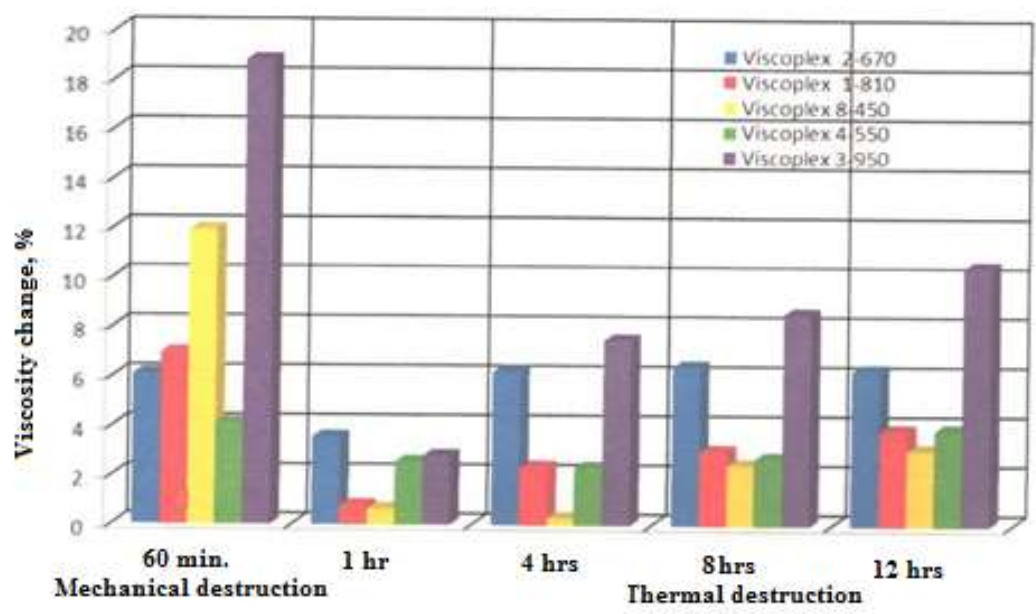

Figure 1. Comparative results of mechanical and thermal destructions of viscosity additives. 
Insignificant changes in viscosity index of additive oil samples after testing for 1-12 hours at high temperature $\left(200^{\circ} \mathrm{C}\right)$ indicate their high resistance against themal destruction.

As Table 2 shows viscosity change of Viscoplex-1-810; 8-450 and 4-550 additives is $(3.08-3.88 \%)$. These indices make it possible to use Viscoplex additives in creating various high-viscosity oils based on Baku distilled oils. Figure 1 shows the comparative results of mechanical and thermal destruction of viscosity additives.

Qualification test results and physicalchemical indices characterizing new oil samples are given in the Table 3.

Table 3. Physical-chemical and operation properties of $M-10 \Gamma_{2} \mathrm{k}$ and $M-14 \Gamma_{2}$ oils

\begin{tabular}{|c|c|c|c|c|c|}
\hline Parameters & $\begin{array}{l}\mathrm{M}-10 \Gamma_{2} \mathrm{k} \\
\Gamma \mathrm{OCT} \\
8581-78\end{array}$ & $\begin{array}{l}\mathrm{M}-10 \Gamma_{2 K} \\
\text { Comp.I }\end{array}$ & $\begin{array}{c}\mathrm{M}-14 \Gamma_{2} \\
\Gamma \mathrm{OCT} \\
12337-84\end{array}$ & $\begin{array}{l}\text { M-14 } \Gamma_{2} \\
\text { Comp.II }\end{array}$ & $\begin{array}{l}\text { Test } \\
\text { method }\end{array}$ \\
\hline $\begin{array}{r}\text { Kinematic viscosity, } \mathrm{mm}^{2} / \mathrm{s}, \\
100^{0} \mathrm{C}\end{array}$ & $11.0 \pm 0.5$ & 11.26 & $13.5-14.5$ & 13.5 & $\begin{array}{l}\text { ASTM } \\
\text { D445 }\end{array}$ \\
\hline Viscosity index, not less than & 85 & 87 & 90 & 90 & $\begin{array}{l}\text { ASTM } \\
\text { D2270 }\end{array}$ \\
\hline $\begin{array}{l}\text { Alkali number, } \mathrm{mg} \mathrm{KOH} / \mathrm{g} \text { oil, } \\
\text { not less than }\end{array}$ & 6.0 & 7.3 & 7.0 & 7.3 & $\begin{array}{l}\text { ASTM } \\
\text { D4739 }\end{array}$ \\
\hline $\begin{array}{l}\text { Sulfated ash content, } \% \text { not } \\
\text { more than }\end{array}$ & 1.15 & 0.99 & 1.3 & 1.0 & $\begin{array}{c}\text { ASTM } \\
\text { D874 }\end{array}$ \\
\hline $\begin{array}{l}\text { Mass of mechanical mixture, } \% \text {, } \\
\text { not much }\end{array}$ & 0.015 & 0.015 & 0.01 & 0.009 & $\begin{array}{l}\text { ASTM } \\
\text { D2273 }\end{array}$ \\
\hline Water mass, $\%$, not more than & trace & Trace & trace & trace & $\begin{array}{l}\text { ASTM } \\
\text { D95 }\end{array}$ \\
\hline $\begin{array}{l}\text { Combusion temperature by open } \\
\text { cup tester, }{ }^{0} \mathrm{C} \text {, not lower than }\end{array}$ & 220 & 231 & 220 & 225 & $\begin{array}{l}\text { ASTM } \\
\text { D92 }\end{array}$ \\
\hline Freezing point, ${ }^{0} \mathrm{C}$, not higher & $\begin{array}{l}\text { Negative } \\
15\end{array}$ & $\begin{array}{l}\text { Negative } \\
22\end{array}$ & $\begin{array}{c}\text { Negative } \\
12\end{array}$ & $\begin{array}{l}\text { Negative } \\
16\end{array}$ & $\begin{array}{l}\text { ASTM } \\
\text { D97 }\end{array}$ \\
\hline $\begin{array}{l}\text { Corrosion on ГOCТ } 3778-77 \text { C- } \\
1 \text { and } \mathrm{C}-2 \text { lead plates } \mathrm{q} / \mathrm{m}^{2} \text {, }\end{array}$ & no & No & no & no & $\begin{array}{l}\text { ГОСТ } \\
20502 \\
\end{array}$ \\
\hline $\begin{array}{l}\text { Detergent properties, } \Pi 3 \mathrm{~B} \text {, ball, } \\
\text { not more than }\end{array}$ & 0.5 & 0.5 & 0.5 & 0.5 & $\begin{array}{c}\text { ГОСТ } \\
5726 \\
\end{array}$ \\
\hline $\begin{array}{l}\text { Oxidative resistance during } \\
\text { induction period of deposit, } 50 \\
\text { hrs. }\end{array}$ & resistant & Resistant & resistant & resistant & $\begin{array}{l}\text { ГОСТ } \\
11063\end{array}$ \\
\hline $\begin{array}{l}\text { Density, } 200^{\circ} \mathrm{C}, \mathrm{kq} / \mathrm{m}^{3} \text {, not more } \\
\text { than }\end{array}$ & 905 & 903 & 905 & 902 & $\begin{array}{l}\text { ASTM } \\
\text { D4052 }\end{array}$ \\
\hline
\end{tabular}

Qualification tests, detergent, antiwear, motor. Before testing $6.3 \mathrm{~kg}$ of oil was injected anticorrosion properties of $\mathrm{M}-10 \Gamma_{2 \mathrm{~K}}$ and $\mathrm{M}$ - into the engine and tested for $5 \mathrm{hrs}$ in an $14 \Gamma_{2}$ engine oils were determined at Д-240 estimated mode (Table 4).

Table 4. Operating mode of testings in idling Д-240 engine

\begin{tabular}{|c|c|c|c|}
\hline Operation mode & $\begin{array}{c}\text { Engine power } \\
\text { ktv.(at.g.) }\end{array}$ & $\begin{array}{c}\text { Rotation } \\
\text { frequency of } \\
\text { crankshaft } \\
\text { r/min }\end{array}$ & $\begin{array}{c}\text { Test time } \\
\text { (min.) }\end{array}$ \\
\hline
\end{tabular}




\begin{tabular}{|l|c|c|c|}
\hline Running idle & - & 800 & 20 \\
\hline Running idle & - & 1000 & 20 \\
\hline Running idle & - & 1800 & 20 \\
\hline Load & $11.95(16.25)$ & 1800 & 30 \\
\hline Load & $19.12(26.0)$ & 1800 & 60 \\
\hline Load & $23.9(32.5)$ & 1800 & 60 \\
\hline Load & $38.25(52.0)$ & 1800 & 60 \\
\hline Full loading & $41.8(56.0)$ & 1800 & 20 \\
\hline Running idle & - & 1000 & 10 \\
\hline
\end{tabular}

Where the control operation mode of testings on Д-240 engine is running idle, the loading of the engine power begins from 11.95 (16.25) kvt(at.g.) to 38.25 (52.0) kvt(at.g.), at full loading it is 41.8 (56.0) kvt(at.g.). Rotation frequency of crankshaft in the course of running idle is $800-1800$, if full loading it is $1800 \mathrm{r} / \mathrm{min}$ (Table 4).

In the course of control process, temperature of oil and cooling water is $90 \pm 5^{0} \mathrm{C}$, pressure of oil in the basic oil line is $0.25 \pm 0.05 \mathrm{mPa}$; in 5 hours the engine was emptied from oil and testing began after adding $12.6 \mathrm{~kg}$ of new oil, the testing was carried out without oil for 120 hours, the testing of each repeated cycle was carried for
$7.5 \mathrm{hrs}$.

In the course of 20 min.,30, 60, $90 \mathrm{hrs,}$ $200 \mathrm{sm}^{3}$ of oil sample was taken and in $120 \mathrm{hrs}$ of operation $400 \mathrm{sm}^{3}$ of oil sample was taken and analyzed.

Amount of the oil taken was restorated through adding oil. Depending on testing period, the deposit content is $0,25 \%$ (20 min) on coke ГОСТ 19932-99 having been formed in oil during the testing, i.e. at the end of the test in $120 \mathrm{hrs}$ it is $1,2 \%$.

With due regard for quality indices of newly prepared $\mathrm{M}-10 \Gamma_{2} \mathrm{~K}$ (API CC, SAE $15 \mathrm{~W}$ 30) (I) and M-14 $\Gamma_{2}$ (API CC, SAE $15 \mathrm{~W}-40$ ) (II), oil samples are presented in Table 5.

Table 5. Change of quality indices of oil samples during testing in Д-240 engine

\begin{tabular}{|c|c|c|c|c|c|c|c|c|c|c|}
\hline \multirow[t]{2}{*}{$\begin{array}{c}\text { Test } \\
\text { period }\end{array}$} & \multicolumn{2}{|c|}{$\begin{array}{c}\text { Kinematic } \\
\text { viscosity, } \\
\mathrm{mm}^{2} / \mathrm{s}, 100^{0} \mathrm{C}\end{array}$} & \multicolumn{2}{|c|}{$\begin{array}{c}\text { Alkali } \\
\text { number, } \\
\text { mqKOH/q }\end{array}$} & \multicolumn{2}{|c|}{$\begin{array}{c}\text { Acid } \\
\text { number, } \\
\text { mqKOH/q }\end{array}$} & \multicolumn{2}{|c|}{$\begin{array}{c}\text { Sulfated ash, } \\
\%\end{array}$} & \multicolumn{2}{|c|}{$\begin{array}{c}\text { Combustion } \\
\text { temperature, } \\
{ }^{0} \mathrm{C}\end{array}$} \\
\hline & I & II & I & II & I & II & I & II & I & II \\
\hline $20 \mathrm{~min}$ & 11.34 & 13.28 & 6.95 & 7.01 & - & - & 0.93 & 1.04 & 230 & 225 \\
\hline $30 \mathrm{hrs}$ & 11.85 & 13.90 & 8.87 & 6.54 & 0.68 & 0.05 & 1.17 & 1.10 & 215 & 220 \\
\hline $60 \mathrm{hrs}$ & 12.14 & 14.20 & 5.48 & 5.10 & 0.99 & 0.62 & 1.25 & 1.18 & 200 & 228 \\
\hline $90 \mathrm{hrs}$ & 13.20 & 14.98 & 4.03 & 4.01 & 1.22 & 0.91 & 1.31 & 1.21 & 205 & 210 \\
\hline $120 \mathrm{hrs}$ & 14.65 & 15.46 & 3.11 & 2.98 & 1.31 & 1.1 & 1.48 & 1.28 & 210 & 212 \\
\hline
\end{tabular}

The changes during testings are presented for both oils in the figures 2 and 3 . 


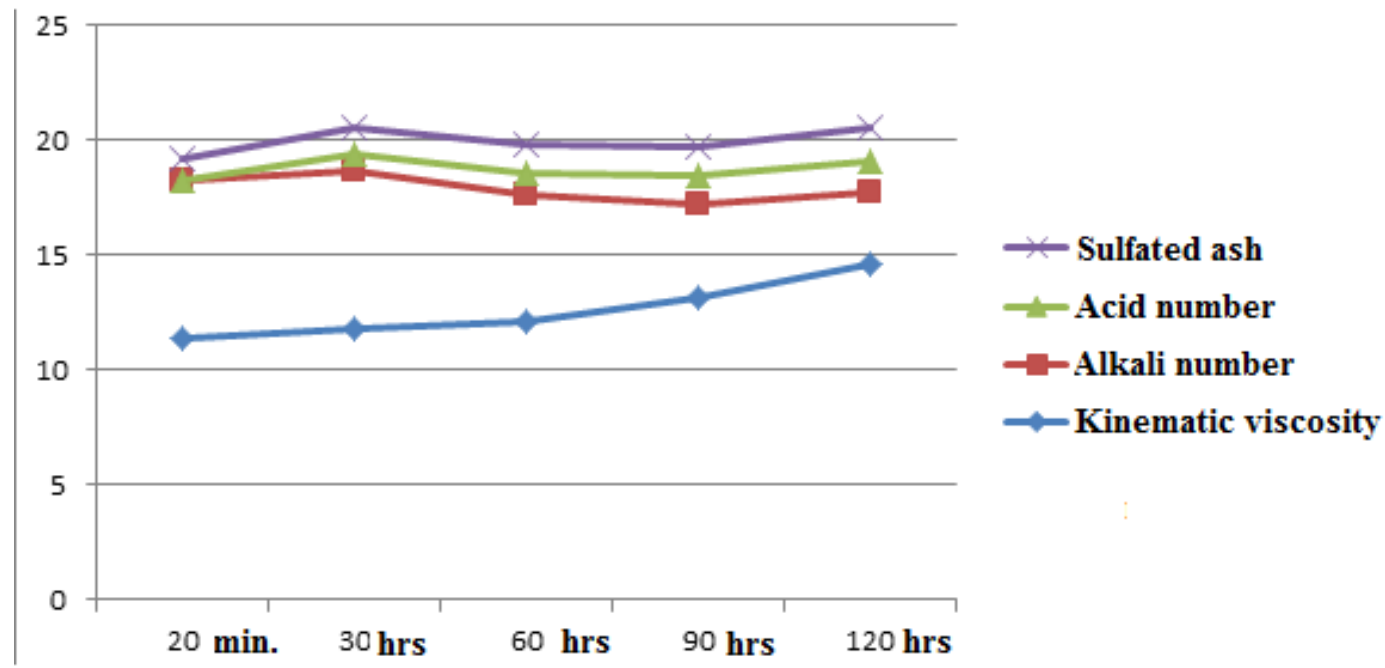

Figure 2. Testing results of M-10Г ${ }_{2} \mathrm{~K}$ oil in engine Д-240

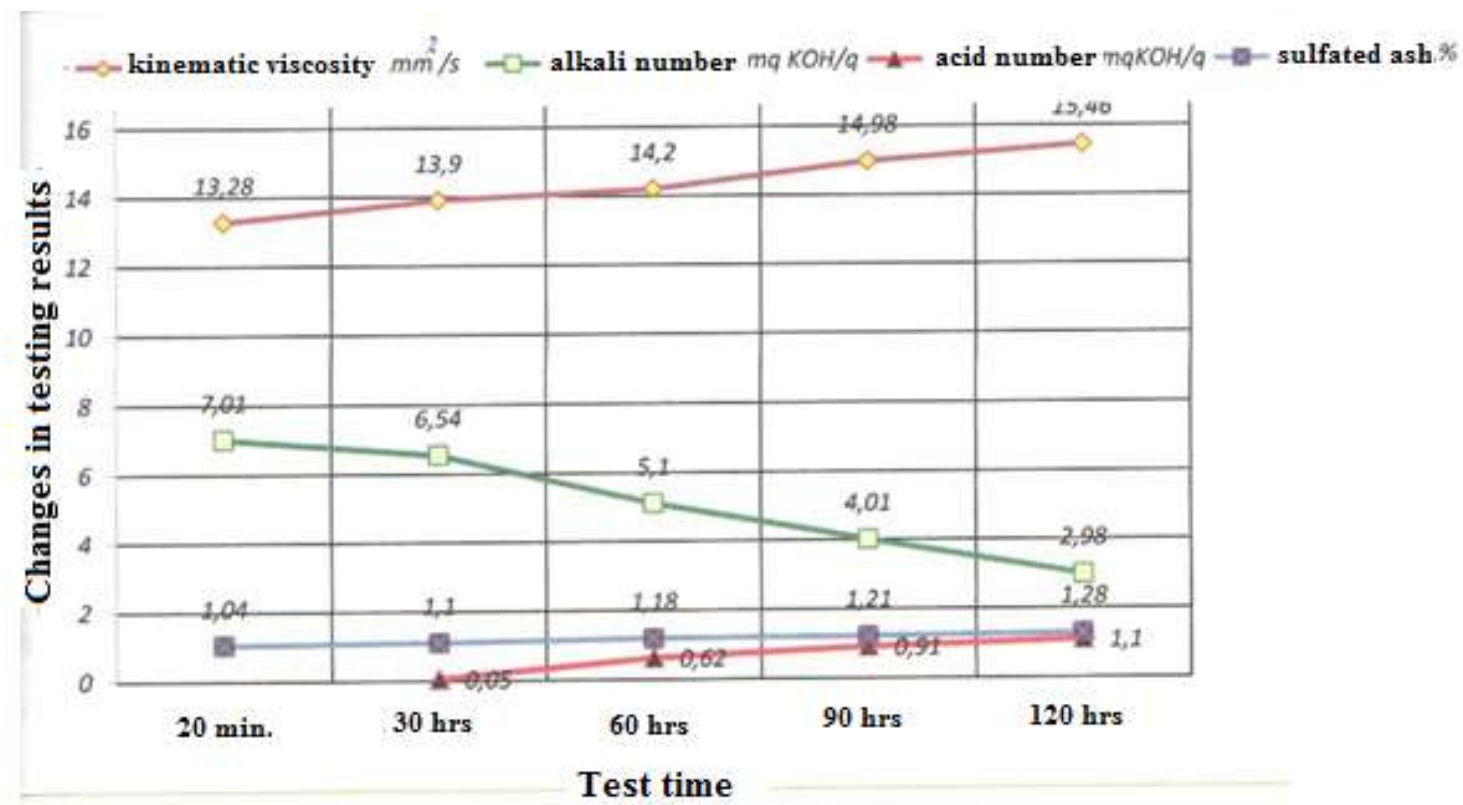

Figure 3. Testing results of $M-14 \Gamma_{2}$ oil in engine Д-240

After the test period came to an end, engine crankcase was emptied from oil and weighted, the amount of loss calculated $(q / s)$ and engine dismantled and analyzed: detergent, anticorrosion and antiwear properties were determined.

Test results of experimental samples of new analogues of motor oils are given in Table 6. 
Table 6. Test results of experimental samples of $\mathrm{M}-10 \Gamma_{2} \mathrm{~K}$ and $\mathrm{M}-14 \Gamma_{2}$ motor oils in engine Д-240.

\begin{tabular}{|c|c|c|c|c|}
\hline \multirow[t]{2}{*}{ PARAMETERS } & \multicolumn{4}{|c|}{ RESULTS } \\
\hline & $\begin{array}{c}\mathrm{M}-10 \Gamma_{2} \mathrm{k} \\
\text { ГОСТ } \\
8581-78 \\
\text { standard }\end{array}$ & $\begin{array}{c}\mathrm{M}-10 \Gamma_{2} \mathrm{k} \\
\text { Sample. } \\
\text { ( I ) }\end{array}$ & $\begin{array}{c}\mathrm{M}-14 \Gamma_{2} \\
\mathrm{TSh} \mathrm{Az} \\
3536814- \\
008-2004 \\
\text { standard }\end{array}$ & $\begin{array}{c}\mathrm{M}-14 \Gamma_{2} \\
\text { Sample. } \\
\text { ( II ) }\end{array}$ \\
\hline $\begin{array}{l}\text { 1.Determination of detergent property } \\
\text { 1.1.Mobility of piston ring, ball }\end{array}$ & - & 0 & 0 & 0 \\
\hline 1.2.Lacquer, soot in ditches & - & 3.17 & - & 3.9 \\
\hline 1.3.Pollution of screens, lacquer, soot, ball & - & 0.95 & - & 1.2 \\
\hline $\begin{array}{l}\text { 1.4.Pollution of side surface of a piston, } \\
\text { ball }\end{array}$ & - & 0 & - & 0 \\
\hline $\begin{array}{l}\text { 1.5.Pollution of internal part of a piston, } \\
\text { ball }\end{array}$ & - & 0.5 & - & 0.1 \\
\hline Pollution of a piston, ball & 6.5 & 4.22 & 10 & 6.2 \\
\hline $\begin{array}{l}\text { 2.Determination of wear property } \\
\text { 2.1. Wear of piston rings, } \mathrm{mg} \text {, }\end{array}$ & 90 & 95.3 & - & 69.9 \\
\hline a) including, I ring, $\mathrm{mg}$ & 35.4 & 32.5 & - & 21 \\
\hline $\begin{array}{l}\text { 3. Determination of corrosion property } \\
\text { 3.1. Wear of connecting rod inserts, } \mathrm{mg}\end{array}$ & 54 & 58 & - & 31 \\
\hline a) up & 45 & 46 & - & 26 \\
\hline b)down & 9 & 12 & - & 5 \\
\hline $\begin{array}{l}\text { 4.Amount of soot in piston, } \\
\text { g/cylinder }\end{array}$ & - & 1.05 & - & 1.54 \\
\hline a) in ditches & - & 0.22 & - & 0.20 \\
\hline b) in piston & - & 0.83 & - & 1.52 \\
\hline 5.Oil loss consumption, g/hour & 70 & 50.8 & 70 & 52 \\
\hline
\end{tabular}

Parameters of detergent properties are indicative that experimental oil provides full mobility of piston rings and makes it possible to assess the contamination with lacquer, soot in separate parts of a piston is within permitted maximum limit. Tests show that the set of piston rings and connecting rod inserts are exposed to less mass loss antiwear, and anticorrosion properties of experimental oil are very high. When the installation works depending on the quality of oil, its anti cinder or soot property, including piston rings and ditches, oil washing rings, side of a piston and combustion camera are viewed.

Detergent property of oil is determined through evaluating the pollution of piston ring mobility, screens and piston bottom with soot and lacquer formed in ditches. Tests show that newly prepared oils in Д-240 engine are notable for total value of mobility of piston rings and lacquer, soot and formed in different parts of piston and pollution by ГОСТ to make up 4.22 against 6.5 for $\mathrm{M}-10 \Gamma_{2} \mathrm{~K}$; however, for $\mathrm{M}-14 \Gamma_{2}$ oil it is 6.2 against 10.0. These parameters are positive results for newly prepared $\mathrm{M}-10 \Gamma_{2} \mathrm{~K}$ and $\mathrm{M}-14 \Gamma_{2}$ oils. 


\title{
Conclusion
}

New $\mathrm{M}-10 \Gamma_{2 \mathrm{k}}$ and $\mathrm{M}-14 \Gamma_{2}$ (API CC, multifunctional alkylphenol additives AKISAE 15W-30 and API CC, SAE 15W -40) 115B and AKI-150. Qualification tests show lubricating compositions based on M-8 and M- that new lubricating compositions can 12 Baku oils were prepared through the use of effectively substitute its analogues.

\section{References}

1.MamedovaA.Kh., Kyazim-zade A.K., Nagiyev E.A. Detergent properties of some modifications of alkylphenolate additives. Oil refining and petrochemistry. 2007, no.10, pp. 32-35.

2. Kapustin V.M., Tonkonogov B.P., Fuchs I.G. /Oil refining technology. Part 3. Production of oil lubricants. Moscow: Himiya Publ., 2014, pp.325.

3. Shkolnikov V.M. Encyclopedic dictionary reference. Moscow, 2010, 756 p.
4. Farzaliev V.M., Javadova A.A., Azimov E.V. Lubricating compositions for highly accelerated diesel engines. / Prospects for the development of chemical processing of combustible minerals. St. Petersburg, 2006, p.159.

5. Patent № I 20080202 (2008). Azerbaijan.

6. Patent № I 20170014 (2017). Azerbaijan.

7. Folders KK, Semenido EG. / Motor and reactiveoils and liquids. Leningrad: HimiyaPubl., 1964, 704 p.

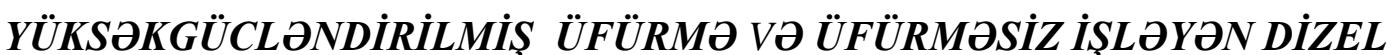 MÜHORRIKLORI ÜÇÜN SÜRTKÜ KOMPOZISIYYALARI}

\section{Y.B.Ramazanova}

\author{
AMEA akad.Ә.M.Quliyev adına Aşqarlar Kimyası İnstitutu \\ Az1029, Bakı ş., Böyükşor şossesi, 2062-ci mahalla \\ +994503277550; e-mail: pishnamazzadeh@mail.ru
}

Müasir dizel mühərriklərində metal konstruksiyaların mütəmadi təkmillaşməsi bu müharriklarda istifado edilon motor yağlarının yeni, daha keyfiyyatli analoqlarının yaradılmasını aktual edir. Son illor yeni modifikasiyalı çoxfunksiyalı AKI seriyalı alkilfenolların $\left(\mathrm{C}_{8}-C_{12}\right)$ formaldehid va aminlorla kondensloşmə məhsullarının kalsium duzlarının totqiqi vo tətbiqi sahəsinda aparlan maqsadyönlü işlar $M-10 \Gamma_{2} k$ va $M-14 \Gamma_{2}$ (API CC, SAE 15W-30; API CC, SAE 15W-40) markalı sürtkü kompozisiyalarının yaradılması ila naticalənmişdir. Bakı neftlorindən alınan $M-8$ vo M-12 baza yă̆larının kompaundu, Aşqarlar Kimyası Institutunda sintez edilmiş çoxfunksiyalı alkilfenol tipli aşqarlar vo "Evonik" firmasının Viscoplex (V) seriyalı özlülük aşqarları ilo yaradılmış yeni $M-10 \Gamma_{2} k$ və M-14 $\Gamma_{2}$ (API CC ,SAE 15W-30; API CC, SAE 15W-40) markalı sürtkü kompozisiyalart kvalifikasiya sinaqları ilə qiymətləndirilmiş, Д-240 markalı mühərrikdə sinaqdan keçirilmişdir.

Açar sözlor: motoryă̆l, aşqar, sürtkü kompozisiyasl, mühərrik sınă̆l,korroziya, yeyilmə. 


\title{
СМАЗОЧНЫЕ КОМПОЗИЦИИ ДЛЯ ВЫСОКОФОРСИРОВАННЫХ ДИЗЕЛЬНЫХ ДВИГАТЕЛЕЙ, РАБОТАЮЩИХС НАДДУВОМ И БЕЗ НАДДУВА
}

\author{
Ю.Б.Рамазанова \\ Институт химии присадок им. акад. А. М. Кулиева Национальной АН Азербайджана \\ Az1029, г Баку, Бёюкшорское шоссе, 2062-ой квартал \\ +994503277550; e-mail: pishnamazzadeh@mail.ru
}

Постоянное усовершенствование металлических конструкций современныхдизельных двигателей делает актуальным создание новых, более качественных аналогов моторных масел, применяемых в них. В последние годы целенаправленныле работы, проводимые в области исследования и применения многофункичиональных алкилфенольных присадок серии $A K \dot{I}\left(C_{8}-C_{12}\right)$, являющихся кальциевыми солями продуктов конденсаџии формальдегида с различными аминами, завершились созданием новых смазочных композиций марок M-10Г 2 и и M-14Г 2 (API CC, SAE 15W30; API CC, SAE 15W--40).Опьтные образиьь смазочных композииий, созданные на основе компаунда базовых масел М-8 и М-12, полученных из Бакинских нефтей, алкилфенольных присадок, синтезированных в Институте Химии Присадок, и вязкостных присадок серии Viscoplex (V) фирмы «Эвоник», были оценень результатами квалификационных испытаний, проведенных на двигателе Д-240.

Ключевые слова: моторное масло, присадка, смазочная композиция, испытание двигателя, коррозия, износ. 